Article

\title{
Environmental Comfort Indicators for School Buildings in Sustainability Assessment Tools
}

\author{
Tatiana Santos Saraiva $^{1, *}$, Manuela de Almeida ${ }^{2}$ (D) Luís Bragança $^{2}$ and Maria Teresa Barbosa ${ }^{3}$ \\ 1 International Doctoral Program in Sustainable Built Environment, School of Engineering, Minho University, \\ Guimarães 4800058, Portugal \\ 2 Department of Civil Engineering, School of Engineering, Minho University, Guimarães 4800058, Portugal; \\ malmeida@civil.uminho.pt (M.d.A.); braganca@civil.uminho.pt (L.B.) \\ 3 Department of Civil Engineering, Federal University of Juiz de Fora, Juiz de Fora 36036900, Brazil; \\ teresa.barbosa@engenharia.ufjf.br \\ * Correspondence: saraivaus@yahoo.com; Tel.: +55-96-98106-1627
}

Received: 13 February 2018; Accepted: 30 May 2018; Published: 2 June 2018

\begin{abstract}
Decades ago, the only requirement to construct a building was to give men the right conditions for the execution of their work or leisure activities. With the development of knowledge about the internal and external environments of buildings, other requirements have been added such as the issue of user comfort. New construction techniques have been incorporated and new products have been created to improve internal environment comfort. This research addressed the importance of using indicators related to environmental comfort in sustainability assessment tools applied to school buildings. It also considered the importance of environmental issues for the good performance of human beings, and the harmonious coexistence of the comfort indicators indoor air quality, thermal comfort, visual comfort, acoustic comfort and ergonomic comfort based on data gathered in research carried out with users of high schools (only students). This research was carried out in two different cities of different countries, Guimarães (Portugal) and Juiz de Fora (Brazil), that have similar characteristics of teaching standards and climate conditions (temperature and air humidity). In this study, interviews were made through questionnaires and, later, the information collected was analyzed. This study demonstrates the need to include an ergonomic indicator for school buildings in sustainability assessment tools.
\end{abstract}

Keywords: comfort indicators; assessment tools; sustainability in school buildings

\section{Introduction}

Since the 1970s, architecture has been slowly reviving its concern with local climate, human comfort and environmental impacts on a global level, resulting in bioclimatic architecture. According to this concept of architecture, a building is responsible for the comfort of human beings, establishing a relationship between local climate and the search for better conditions of internal environment to provide user satisfaction in visual, hydrothermal, acoustic, ergonomic, emotional and cultural aspects [1].

In the last decades, the negative effects caused to the environment by the construction industry have grown, resulting in an increased worry about the measures related to the sustainability of buildings, expressed by indexes, ratings or sustainability indicators. These indicators and ratings are used in different contexts [2]. Several certification systems have been developed to assess sustainable buildings and to better inform building users and, therefore, improve sustainability. Nowadays, there is a huge variety of certification methodologies, using different sets of indicators, such as LEED and BREEAM, in which the indicators are measured through the check in system, and SBTool, in which 
the indicators are measured according to the percentage value associated with each environmental indicator [3].

School buildings are one of the most important facilities in a community given that students spend about $25 \%$ of their time inside classrooms. Moreover, a school usually has a considerably higher occupancy rate than any other type of building [4]. It is very important for schools to have a level of indoor comfort that will not affect children's health or intellectual performance. Besides, student examination grades have proportionally decreased in relation to the increase in complaints concerning Indoor Environmental Quality (IEQ) factors such as indoor air quality and thermal, ergonomic, visual and acoustic comfort [5].

However, there are many assessment tools and comparing their results is very difficult because they were developed for different types of buildings or different phases of the construction process, considering different perspectives of the building life cycle, or using different databases or guidelines. Therefore, it is necessary to implement a specific methodology for each region, which is emphasized in this paper.

This study addressed the importance of using comfort indicators in methodologies to assess the sustainability of schools based on questionnaires applied in high schools in different cities and different countries where the concept of sustainable development is more widespread: Guimarães (Portugal) and Juiz de Fora (Brazil). This methodology is intended to minimize uncertainties and errors that may occur in the parameters that allowed the evaluation of the concept of Indoor Environmental Quality in different cultures.

It should be noted that the schools surveyed could not represent the whole country where they are located (Portugal or Brazil) since they have great cultural and climatic diversity. The cities of Juiz de Fora and Guimarães have similar average annual temperature, average annual humidity, building characteristics and classroom layout, a result of Portuguese colonization. In addition, despite cultural differences, the results were similar for both cities.

The significance of this paper lies in the presentation and discussion of classroom conditions that influence children's educational performance and the emphasis of the IEQ indicator for the student's well-being and attainment. Finally, the authors hope that this research may provide the basis for future studies in other countries [6].

\section{Review of Comfort Indicators}

Indoor Environmental Quality (IEQ) is a popular theme in all sustainable development assessment tools aimed at increasing the comfort, health and safety of a building's occupant [7]. In most methodologies for schools, such as LEED for School, SBTool for School and BREEAM Education, the most common indicators are: thermal, acoustic and noise comfort; ventilation and contamination level; and illumination and lighting [8]. A brief description of these indicators is presented below:

(i) Indoor Air Quality (IAQ) is defined as the building's ability to maintain the health and well-being of its users through adequate temperature, air quality and air humidity [9]. Measurement of indoor air quality is made to verify if internal pollutant concentrations are within the limits established by local laws [10]. One of the most important environmental parameters that need to be controlled is carbon dioxide and that can only be achieved through proper ventilation. Inadequate IAQ conditions in classrooms can lead to a reduction in children's performance of up to $30 \%$ [11].

(ii) Thermal comfort is the condition of mind that generates satisfaction with the thermal environment. [12]. Human thermal comfort is standardized by International Standard ISO 7730 (1994), which is based on studies conducted in 1970 by Fanger, Denmark [13]. According to Barrett et al. (2015), thermal comfort is related to the learning progress, i.e., students usually perform better in the classroom where the temperature is easy to control [14].

(iii) Visual comfort is the main factor considered regarding the lighting needs of a building. It is related to the set of conditions in a specific environment in which human beings can develop 
their visual tasks with less effort, with reduced risk of accidents and damage to the eye, and with maximum visual precision and accuracy [14]. Integrating objective and subjective aspects, three fundamental aspects of learning spaces are achieved: efficiency, comfort and performance modulated by appropriate design [15].

(iv) Acoustic comfort is the area of physics that studies sound, covering reception, spread, genesis and sound insulation. Acoustic comfort depends on sound intelligibility, reverberation time and noise control [16]. Noise can be generated from the school environment, common areas or inside the classroom. Thus, it is very important to isolate areas that produce excessive noise so that acoustic problems are reduced in the classroom. The design should avoid openings to streets and, as far as possible, reduce windows and doors [17].

(v) Ergonomic comfort is the study of the adaptation of a man to the work, involving the physical environment and organizational aspects related to the activities performed on site. School furniture design demonstrates a close link between school desks, health problems and discipline in class [18]. Anthropometric measurements of students vary between different ethnic groups, cultures, ages, races and genders. It is difficult for a furniture designer to determine specific dimensions for many students [19]; therefore, the best option to solve this problem is the use of adaptable desks.

\section{Materials and Methods}

This research aimed to analyze the importance of environmental comfort in school buildings in the cities of Guimarães (Portugal) and Juiz de Fora (Brazil), since they have similar temperature, humidity and classroom conditions (room size, number of students per room, and others). The schools studied in this research are traditional in their respective cities and were built in the nineteenth century.

The city of Guimarães is considered the ninth city in quality of life in Portugal (of a total of 338 cities) and has good education and health systems. The climate is hot and tempered with an average annual temperature of $14{ }^{\circ} \mathrm{C}$, average annual air humidity of $81 \%$, and annual precipitation above $1500 \mathrm{~mm}$. Francisco de Holanda High School, subject of this study, was built in 1864 and, in 2011, underwent a major renovation for the purpose of modernization, and currently holds the title of "standard school" in Portugal [20].

The city of Juiz de Fora is considered the seventh city in quality of life in the state of Minas Gerais State, Brazil (of a total of 853 cities in this state). The climate is hot and tempered with an average annual temperature of $16{ }^{\circ} \mathrm{C}$, average annual air humidity of $80 \%$, and annual precipitation above $1500 \mathrm{~mm}$. Colégio Cristo Redentor and Colégio Santa Catarina, subjects of this study, were built in 1891 and 1900, respectively. These buildings are a result of the influence of Portuguese colonization [21].

In this study, the questionnaire was based on Ricardo Mateus' thesis [22], since it was developed to be applied to students in Guimarães, Portugal. The adapted questionnaire (multiple-choice answers) was used in high school students to identify the Indoor Environmental Quality (IEQ) conditions in the school buildings. After that, a statistical analysis was carried out using Microsoft Excel, with a level of probability of 0.05 (reliability coefficient), to evaluate the performance of the answers. Through the analyses of the results, it was possible to understand which types of environmental comfort issues are more important to the student.

To minimize errors, the questionnaires were applied in winter, when the temperatures were similar, $8-15{ }^{\circ} \mathrm{C}$ in Juiz de Fora and $8-18{ }^{\circ} \mathrm{C}$ in Portugal. Air humidity was also high in both cities (about $80 \%$ ).

The multiple-choice answers of the questionnaires were sorted according to the level of importance to the students and to how they interfere in their well-being and learning process, ranging from comfort (very good) to extreme discomfort (insufficient). The complete survey is presented in the Appendix A this article and comprises six questions. 


\section{High School in Portugal}

Francisco de Holanda High School (FHHS) was initially built to be an industrial school in 1864 . In 1959, a major renovation took place with the creation of its main building with three floors. In 2011, there were new major renovations carried out by the Parque Escolar Company (in Portuguese, EPE) and the school still uses a great part of the resources and equipment installed by the company. The school represents the current school construction standard in Portugal [21], that is, it is a "Portuguese standard school".

The Program for the Modernization of Schools for Secondary Education (PMEES) aimed to place Portuguese education in a position of international reference. The PMEES includes interventions in 332 schools. This program sets standards for all schools that are or will be reformed by the EPE. Table 1 shows several standards adopted by the PMEES regarding classroom comfort.

Table 1. Standards adopted by PMEES regarding classroom comfort. FHHS.

\begin{tabular}{ll}
\hline Content & Description \\
\hline Dimensions & $\begin{array}{l}\text { Normal classroom }\left(50 \mathrm{~m}^{2}\right), \text { small }\left(20 \text { to } 40 \mathrm{~m}^{2}\right) \text { and large }\left(100 \mathrm{~m}^{2}\right) \\
\text { Minimum classroom height: } 2.70 \mathrm{~m}\end{array}$ \\
\hline \multirow{2}{*}{ Air quality } & $\begin{array}{l}\text { Transverse natural ventilation in all spaces of continuous occupation. } \\
\text { Occupancy of room }=26 \text { people; air renewal rate }=30 \mathrm{~m}^{3} / \mathrm{h} \text { person }\end{array}$ \\
\hline & $\begin{array}{l}\text { Natural and or Forced Ventilation + Passive Cooling } \\
\text { Heat Recovery /Cooling Ventilation (Exchangers) } \\
\text { Roof insulation (strong insulation) } \\
\text { Double glasses in windows Exterior Wall Insulation } \\
\text { The exterior spans should be double-glazed with heat treatment } \\
\text { Spaces without HVAC, dry bulb temperatures can be between } 18 \text { and } 28{ }^{\circ} \mathrm{C} . \\
\text { Sun protection-allow the passage of } 25-30 \% \text { of the radiation. }\end{array}$ \\
\hline Visual comfort & $\begin{array}{l}\text { Recommended level: } 500 \text { lux, with a maximum of } 10 \mathrm{~W} / \mathrm{mC} \\
\text { 49 W fluorescent lamp, with a minimum of } 99.99 \% \text { purity, }\end{array}$ \\
\hline Acoustic Comfort & $\begin{array}{l}\text { Ceiling with acoustic treatment; } \\
\text { Double glasses }\end{array}$ \\
\hline
\end{tabular}

The questionnaires were applied to high school students from 15 to 18 years old and the environmental comfort verified in this work takes as a base the classroom, where students spend most of their time. The research was done in nine classes, three of each grade, giving a total of 269 students. Table 2 shows the main aspects related to the interview and classroom characteristics, and Table 3 shows the results of the survey, considering a total of $100 \%$ of the interviewed students, which reflects how satisfied students are or not with different types of environmental comfort issues.

Table 2. Main aspects related to the interview and classroom characteristics of FHHS.

\begin{tabular}{ll}
\hline Content & Description \\
\hline Interview Date & 11 January 2017 \\
\hline Number of students in the school & 1400 \\
\hline $\begin{array}{l}\text { Number of student that answered } \\
\text { the questionnaires }\end{array}$ & $269(19.21 \%$ of total $)$ \\
\hline Temperature in the city & $11^{\circ} \mathrm{C}$ to $15^{\circ} \mathrm{C}$ \\
\hline Air humidity & $85 \%$ \\
\hline Temperature in the class & $18^{\circ} \mathrm{C}$ to $22^{\circ} \mathrm{C}$ \\
\hline
\end{tabular}


Table 2. Cont.

\begin{tabular}{ll}
\hline Content & Description \\
\hline Air quality & $\begin{array}{l}\text { Ozonium, formaldehyde, bacteria, legionella, radon, carbon dioxide and } \\
\text { carbon monoxide fungus, particles suspended in air with a diameter of } \\
\text { less than } 10 \mu \text { m and volatile organic compounds presented low results } \\
\text { according to Regulatory Compliance Statement for this construction. }\end{array}$ \\
\hline Mechanical System & $\begin{array}{l}\text { System of ventilation, aiding the entrance of new air, and air } \\
\text { conditioners in every classroom, maintaining the same temperature. }\end{array}$ \\
\hline Window size & $\begin{array}{l}\text { Glasses are double and laminated, separated by a chamber of } \\
\text { dehydrated air with } 12 \text { mm of thickness, helps to maintain the } \\
\text { temperature with efficient energy. }\end{array}$ \\
\hline Window material & $\begin{array}{l}\text { Windows are large (2 windows, H }=1 \text { m and L }=2 \text { m), there are also } \\
\text { skylights in darker places, favoring natural lighting. }\end{array}$ \\
\hline Lamps & $\begin{array}{l}\text { Fluorescent lamps or metal halide lamps are used, providing } \\
\text { adequate illumination. }\end{array}$ \\
\hline Cover Material & The floor is formic; the wall has bright white paint with glass windows. \\
\hline Reverberation time & $\begin{array}{l}\text { 0.75 s, which is high according to EN ISO 3382-2 (0.55 s to 0.60 s), since } \\
\text { the cover material is hard and smooth. }\end{array}$ \\
\hline Sound level outside & $\begin{array}{l}35 \text { db-does not interfere, and there is no noise from rooms close to } \\
\text { the classrooms. }\end{array}$ \\
\hline Sound level inside & $\begin{array}{l}54 \text { to } 71 \mathrm{~dB}, \text { higher than what is established in the European Comfort } \\
\text { Standard EN 15251 (30 to } 45 \mathrm{~dB}) .\end{array}$ \\
\hline $\begin{array}{l}\text { Parque Escolar uses standard and fixed furniture, not adaptable to the } \\
\text { biotype of each student. }\end{array}$ \\
\hline
\end{tabular}

Table 3. Result of the percentages related to the students' level of satisfaction with the different types of environmental comfort indicators at Francisco de Holanda High School, Portugal.

\begin{tabular}{ccccc}
\hline IEQ & $\begin{array}{c}\text { Level 1 } \\
\text { Comfortable }\end{array}$ & $\begin{array}{c}\text { Level 2 } \\
\text { Slightly Uncomfortable }\end{array}$ & $\begin{array}{c}\text { Level 3 } \\
\text { Uncomfortable }\end{array}$ & $\begin{array}{c}\text { Level 4 } \\
\text { Very Uncomfortable }\end{array}$ \\
\hline Thermal & $61 \%$ & $23 \%$ & $10 \%$ & $6 \%$ \\
Lighting & $78 \%$ & $18 \%$ & $4 \%$ & $0 \%$ \\
Acoustic & $54 \%$ & $38 \%$ & $6 \%$ & $2 \%$ \\
Air quality & $72 \%$ & $2 \%$ & $26 \%$ & $1 \%$ \\
Ergonomic & $27 \%$ & $50 \%$ & $19 \%$ & $4 \%$ \\
General & $56 \%$ & $31 \%$ & $12 \%$ & $1 \%$ \\
\hline
\end{tabular}

The statistical analysis between groups was done using Microsoft Excel (Analysis of variance (ANOVA)) regarding the IEQ results for Francisco de Holanda High School. It verified that the Fcalculated $=14.17>$ Ftabulated $=3.23$ (probability of 0.05), i.e., there is significant variability between the data. The students' satisfaction regarding thermal, lighting and air quality comfort was very high, but the satisfaction was somewhat lower regarding acoustic comfort and deficient regarding ergonomic comfort, as described below:

(i) Sixty-one percent of the students stated that they are comfortable with the temperature inside the classroom, which is not a good result considering that this is one of the main problems found in Portuguese buildings and it is advisable that $80 \%$ of the people [12] within the same environment should be comfortable.

(ii) Seventy-eight percent of the students stated that they are comfortable with the lighting inside the classroom, which is a good result. This result is within the expectations. Artificial lighting related to the students' level of comfort in this aspect seems to be quite adequate. 
(iii) Fifty-four percent of the students are comfortable with the noise level. It is a high value considering that it is a classroom. The students' dissatisfaction with the environment has a strong relationship with their productivity. As it was informed in Table 1, the sounds come, mainly, from the inside. The reverberation time ( $0.75 \mathrm{~s})$ and the sound levels (54 to $71 \mathrm{~dB}$ ) are too high.

(iv) Seventy-two percent of the students stated that they are comfortable with the air quality inside the classroom.

(v) Twenty-seven percent of the students stated that they are comfortable with ergonomics. This low result related to the number of students who feel comfortable shows the need for greater concerns with this aspect and, therefore, the inclusion of an indicator related to the ergonomics of desks in the methodologies that evaluate and certify sustainability in school environments.

(vi) Fifty-six percent of the students are comfortable inside the classroom. This is not a good result, mainly due to the level of satisfaction of the students who answered the questionnaire regarding acoustic and ergonomic comfort.

Through the analysis of the information, there is a clear need to support the schools, giving priority to ergonomic and to acoustic comfort related to IEQ in the Portuguese building school.

\section{High Schools in Brazil}

This section presents the questionnaires applied to the students of two high schools chosen in Juiz de Fora. These schools are two of the best and most traditional private schools in the city, both of which have been operating for more than 100 years. Colégio Santa Catarina was built in 1900 and Colégio Cristo Redentor was founded in March 1891 by farmers and industrialists [21]. They are buildings with three floors.

The questionnaires were applied to high school students from 15 to 18 years old and the environmental comfort verified in this work takes as a base the classroom where students spend most of their time. The research was done in six classes, two of each grade and two of each school, reaching 269 students. Table 4 shows the main aspects related to the interview and classroom characteristics and Table 5 shows the results of the survey, considering a total of 100\% of interviewed students, reflecting how satisfied students are or not with different types of environmental comfort issues.

Table 5 reflects how satisfied or not students are with the different aspects of environmental comfort at the Brazilian high schools. The statistical analysis between groups was done using Microsoft Excel (ANOVA) regarding the IEQ results for the Brazilian High Schools. It verified that the Fcalculated $=17.81>$ Ftabulated $=3.09$ (probability equal to 0.05), i.e., there is significant variability between the data. The students' satisfaction regarding thermal, lighting and air quality comfort was very high, but the satisfaction was somewhat lower regarding acoustic comfort and deficient regarding ergonomic comfort, as described below:

(i) Seventy-five percent of the students stated that they are comfortable inside the classroom, which is a reasonable result considering it is advisable that $80 \%$ of the people [12] within the same environment should be comfortable.

(ii) Eighty percent of the students stated that they are comfortable with the lighting in the classroom, which is a good result. This result is within the expectations. Lighting related to the students' level of comfort in this aspect seems to be quite adequate.

(iii) Thirty-eight percent of the students are comfortable with the noise in the classroom. It is a high value considering that it is a classroom. The students' dissatisfaction with the environment has a strong relationship with their productivity. As shown in Table 4, the sounds mainly come from the inside. The reverberation time $(0.86 \mathrm{~s})$ and the sound levels (60 to $65 \mathrm{~dB})$ are too high.

(iv) Seventy-nine percent of the students stated that they are comfortable with air quality in the classroom, which is a good result. This result is within the expectations. 
(v) Twenty-nine percent of the students are feeling comfortable with ergonomics. This low result related to the number of students who feel comfortable is very close to the results found in Portugal (vide Table 3), which show that $27 \%$ of the students are comfortable regarding ergonomics. That emphasizes the need of including the indicator related to ergonomics of desks in the methodologies that evaluate and certify sustainability in school environments.

(vi) Fifty-eight percent of the students feel comfortable with all the factors mentioned. This is not a good result, mainly due to the level of satisfaction of the students who answered the questionnaire regarding the acoustic and ergonomic comfort.

Table 4. Main aspects related to the interview and classroom characteristics in Juiz de Fora.

\begin{tabular}{|c|c|}
\hline Content & Interview and Classroom Characteristics in Juiz de Fora Description \\
\hline Interview Date & 19 July 2017 \\
\hline Number of Students in the school & 1980 \\
\hline $\begin{array}{l}\text { Number of student that answered } \\
\text { the questionnaires }\end{array}$ & $\begin{array}{l}303 \text { ( } 57 \% \text { from Colégio Santa Catarina }+43 \% \text { from Colégio Cristo } \\
\text { Redentor) }\end{array}$ \\
\hline Temperature in the City & $11^{\circ} \mathrm{C}$ to $14^{\circ} \mathrm{C}$ \\
\hline Air humidity & $81 \%$ \\
\hline Temperature in the class & $14^{\circ} \mathrm{C}$ to $18^{\circ} \mathrm{C}$ \\
\hline Air quality & $\begin{array}{l}\text { Ozonium, formaldehyde, bacteria, legionella, radon, carbon dioxide and } \\
\text { carbon monoxide fungus, particles suspended in air with a diameter of } \\
\text { less than } 10 \mu \mathrm{m} \text { and volatile organic compounds presented low results } \\
\text { according to Regulatory Compliance Statement for this construction. }\end{array}$ \\
\hline Mechanical System & $\begin{array}{l}\text { The classrooms of both schools do not have heating systems but they } \\
\text { can maintain the internal temperature. }\end{array}$ \\
\hline Window size & The windows are large, favoring natural lighting. \\
\hline Window material & $\begin{array}{l}\text { Windows are large ( } 2 \text { windows, } \mathrm{H}=1 \mathrm{~m} \text { and } \mathrm{L}=2 \mathrm{~m} \text { ), there are also } \\
\text { skylights in darker places, favoring natural lighting. }\end{array}$ \\
\hline Lamps & Most of the lamps used are fluorescent, offering a good illumination. \\
\hline Cover Material & $\begin{array}{l}\text { The external walls are made of solid bricks, and the windows used are } \\
\text { simple and without special sealing. }\end{array}$ \\
\hline Reverberation time & $\begin{array}{l}0.86 \mathrm{~s} \text {, which is high according to EN ISO } 3382-2(0.55 \mathrm{~s} \text { to } 0.60 \mathrm{~s}) \text {, since } \\
\text { the cover material is hard and smooth. }\end{array}$ \\
\hline Sound level outside & $\begin{array}{l}35 \mathrm{~dB} \text { - does not interfere, and there is no noise from rooms close to } \\
\text { the classrooms. }\end{array}$ \\
\hline Sound level inside & $\begin{array}{l}60 \text { to } 65 \mathrm{~dB} \text {, higher than what is established in the European Comfort } \\
\text { Standard EN } 15251 \text { ( } 30 \text { to } 45 \mathrm{~dB} \text { ). }\end{array}$ \\
\hline Size of chairs and tables & $\begin{array}{l}\text { The schools use standard furniture, not adaptable to the biotype of } \\
\text { each student. }\end{array}$ \\
\hline
\end{tabular}

Table 5. Result of the percentages related to the students' level of satisfaction with the different types of environmental comfort indicators at High Schools in Juiz de Fora, Brazil.

\begin{tabular}{|c|c|c|c|c|}
\hline IEQ & $\begin{array}{c}\text { Level } 1 \\
\text { Comfortable (C) }\end{array}$ & $\begin{array}{c}\text { Level } 2 \\
\text { Slightly Uncomfortable (SU) }\end{array}$ & $\begin{array}{c}\text { Level } 3 \\
\text { Uncomfortable (U) }\end{array}$ & $\begin{array}{c}\text { Level } 4 \\
\text { Very Uncomfortable (VU) }\end{array}$ \\
\hline Thermal & $75 \%$ & $14 \%$ & $9 \%$ & $2 \%$ \\
\hline Lighting & $80 \%$ & $12 \%$ & $6 \%$ & $1 \%$ \\
\hline Acoustic & $38 \%$ & $39 \%$ & $13 \%$ & $10 \%$ \\
\hline Air quality & $79 \%$ & $1 \%$ & $20 \%$ & $1 \%$ \\
\hline Ergonomic & $29 \%$ & $29 \%$ & $28 \%$ & $14 \%$ \\
\hline General & $58 \%$ & $30 \%$ & $11 \%$ & $1 \%$ \\
\hline
\end{tabular}


Through the analysis of the information, there is a clear need to support the schools, giving priority to ergonomic and acoustic comfort without forgetting the other three indicators.

\section{Discussion}

Table 6 and Figure 1 show the differences and similarities between the percentages of environmental comfort perceived by the students of the schools of Juiz de Fora (Brazil) and Guimarães.

Table 6. Comparison of the percentages of the answers given by students of the schools of Juiz de Fora (BR) and Guimarães (PT) regarding environment comfort.

\begin{tabular}{|c|c|c|c|c|c|c|c|c|}
\hline \multirow[t]{2}{*}{ IEQ } & \multicolumn{2}{|c|}{$\begin{array}{c}\text { Level } 1 \\
\text { Comfortable (C) }\end{array}$} & \multicolumn{2}{|c|}{$\begin{array}{c}\text { Level } 2 \\
\text { Slightly Uncomfortable (SU) }\end{array}$} & \multicolumn{2}{|c|}{$\begin{array}{c}\text { Level } 3 \\
\text { Uncomfortable (U) }\end{array}$} & \multicolumn{2}{|c|}{$\begin{array}{c}\text { Level } 4 \\
\text { Very Uncomfortable (VU) }\end{array}$} \\
\hline & (BR) & (PT) & (BR) & (PT) & (BR) & (PT) & (BR) & (PT) \\
\hline Lighting & $80 \%$ & $78 \%$ & $12 \%$ & $18 \%$ & $6 \%$ & $4 \%$ & $1 \%$ & $0 \%$ \\
\hline Acoustic & $38 \%$ & $54 \%$ & $39 \%$ & $38 \%$ & $13 \%$ & $6 \%$ & $10 \%$ & $2 \%$ \\
\hline Air quality & $79 \%$ & $72 \%$ & $1 \%$ & $2 \%$ & $20 \%$ & $26 \%$ & $1 \%$ & $0 \%$ \\
\hline
\end{tabular}

The statistical analysis between groups (Table 6) using Microsoft Excel (ANOVA) regarding the IEQ results for the Brazilian and Portuguese High Schools found that:

(i) For the countries: Fcalculated $=0.02<$ Ftabulated $=2.60$ (probability equal to 0.05 ), i.e., there is no significant variability between countries. The Brazilian students and Portuguese students have the same parameters in building school.

(ii) For the IEQ: Fcalculated $=9.68<$ Ftabulated $=2.60$ (probability equal to 0.05 ), i.e., there is significant variability of IEQ between the countries.

As can be seen in Table 6, the general results of environmental comfort assessments are similar, since the cities of Juiz de Fora (Brazil) and Guimarães (Portugal) have similar characteristics, such as temperature and humidity.

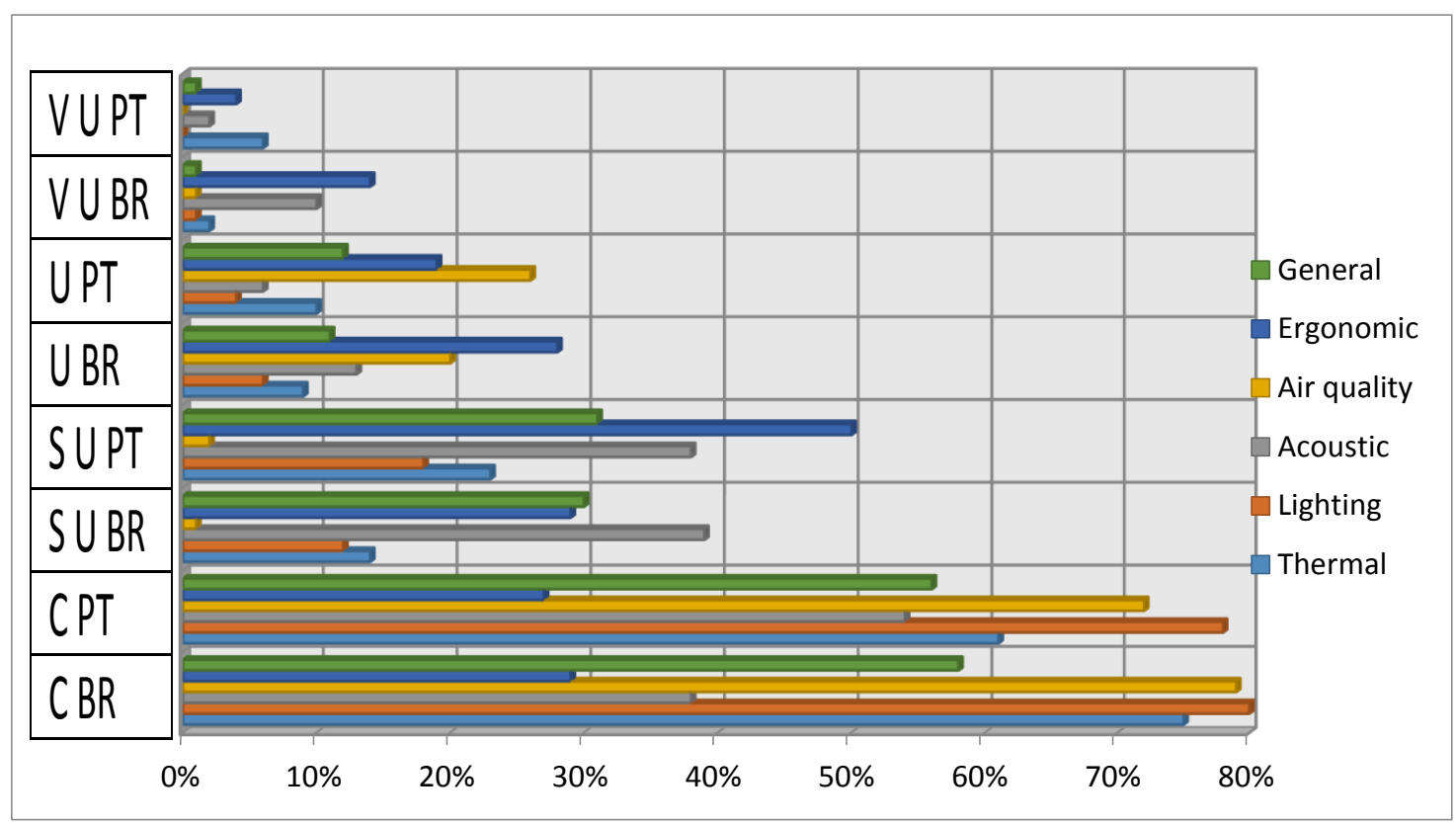

Figure 1. IEQ for Brazilian high school and Portuguese high school. 
The results on acoustic comfort (see Table 6) show that just $38 \%$ of Brazilian students and $54 \%$ of Portuguese students are comfortable. That was so because, at the Brazilian high schools, the sound level inside the class is around 54 to $71 \mathrm{~dB}$ and the reverberation time is $0.86 \mathrm{~s}$, and at the Portuguese school the sound level is 49 to $65 \mathrm{~dB}$ and the reverberation time is $75 \mathrm{~s}$. These values are higher than what is recommended by the European Comfort Standard EN 15251 (30 to $45 \mathrm{~dB}$ ) and EN ISO $3382-2$, ( $0.55 \mathrm{~s}$ to $0.60 \mathrm{~s})$. These high values occur because the classroom's surface materials are smooth and hard, accentuating reverberation, and the walls dividing one room from the other do not have adequate acoustic insulation treatment.

The level of ergonomic comfort has low results (under 30\%), in comparison with other IEQ values because there are standard desks in all schools, which can cause discomfort and muscle pain in the users. Considering that there are large differences in size among teenagers, adaptable portfolios that fit the biotype of each student should be used.

Finally, there is a need to consider the ergonomic comfort of school buildings in sustainability assessment tools because it is very important of environmental issues for the performance of human beings.

\section{Conclusions}

This study made clear the importance of maintaining comfort indicators within a sustainable range, specifically for school environments, since students stay long periods inside the school and comfort interferes in the students' health, concentration and learning. It also aimed to determine the need of including the ergonomic comfort indicator in sustainability assessment tools for school buildings, for the sake of the welfare of the students, since most of the students, $73 \%$ in Portugal and $71 \%$ in Brazil, feel school desks are uncomfortable.

Another aspect observed through the results of the work is that, although there are common characteristics between the cities of Guimarães and Juiz de Fora (such as temperature, humidity and school characteristics), different results were found for most indicators studied. Therefore, there is a clear need of adaptation of this methodology to each location in each country. Brazil has a large territorial area, so several adaptations of the methodology will be necessary to adjust it to the specific needs of each region.

A good sustainability assessment tool interfere with the well-being of the building users and improve quality of life. Moreover, there is a great tendency of local legislation to follow the requirements of the methodology applied to assess sustainability in school buildings, especially when it is widely used by the population, thus bringing great benefits.

The study carried out in Juiz de Fora serves to open precedents for new research in Brazil related to sustainability assessment methodologies specific for schools that may be adapted to different Brazilian regions. This kind of research is unprecedented and necessary considering that sustainability has growing demand around the world and there is a huge demand for this subject in Brazil.

Author Contributions: Conceptualization, T.S.S. and M.A.; Methodology, T.S.S. and M.T.B.; Formal Analysis, M.A., M.T.B. and T.S.S. ; Investigation, T.S.S.; Writing-Original Draft Preparation, T.S.S.; Writing-Review \& Editing, M.A., M.T.B., T.S.S. and L.B.; Project Administration, T.S.S.; Funding Acquisition, T.S.S.

Acknowledgments: The corresponding author wants to thank: the teacher and Administrative Director of Francisco de Holanda High School, Abílio Ferreira, for showing me the school and giving all the necessary information, always with great attention; Parque Escolar Company (EPE) for supplying the necessary material for the execution of the work; and Mrs. Catarina Araujo for helping me in the conception of this article. This research did not receive any specific grant from funding agencies in the public, commercial, or not-for-profit sectors.

Conflicts of Interest: The authors declare that there is no conflict of interest.

\section{Appendix}

Questionnaires-Environmental Comfort Indicators-Students

Grade Date: 
1. Check the feeling of comfort where you are, considering only the temperature.
(a) Comfortable
(b) Very cold
(c) Cold
(d) A little cold
(e) A little hot
(f) Warm
(g) Very warm

2. Check the feeling of comfort, considering only the lighting.
(a) Comfortable
(b) A little uncomfortable with excessive lighting
(c) Uncomfortable with excessive lighting with lighting
(d) Very uncomfortable with excessive lighting
(e) A little uncomfortable with insufficient lighting
(f) Uncomfortable with insufficient lighting
(g) Very uncomfortable with insufficient lighting

3. Check the feeling of comfort, considering only the noise level
(a) Comfortable
(b) Slightly noisy
(c) Noisy
(d) Very noisy

4. Check the feeling of comfort, considering only the level of air quality.
(a) Fresh
(b) Muffled
(c) Odorless
(d) Smelly
(e) Comfortable
(f) A little polluted
(g) Polluted
(h) Very Polluted

5. Check the feeling of comfort, considering only the level of ergonomic comfort, that is, the comfort offered by desks and the movement of students in the classroom.
(a) Comfortable
(b) A little uneasy
(c) Uncomfortable
(d) Very uncomfortable

6. Check the sense of comfort considering all the factors mentioned above.
(a) Comfortable
(b) Slightly uncomfortable
(c) Uncomfortable
(d) Very uncomfortable 


\section{References}

1. Corbella, O.; Yannas, S. Search of a Sustainable Architecture for the Tropics, Environmental Comfort; Publisher Revan: Rio de Janeiro, Brazil, 2003.

2. Reith, A.; Orova, M. Do green neighbourhood ratings cover sustainability. Ecol. Indic. 2015, 48, 660-672. [CrossRef]

3. Rid, W.; Lammers, J.; Zimmerman, S. Analyzing sustainability certification systems in the German housing sector from a theory of social institutions. Ecol. Indic. 2017, 76, 97-110. [CrossRef]

4. Cartieaux, E.; Rzepka, M.; Cuny, D. Internal Air Quality Technical. Ph.D. Thesis, USP Polytechnic School São Paulo, Sao Paulo, Brazil, 1999.

5. Lee, M.; Mui, K.; Wong, L.; Chan, W.; Lee, E.; Cheung, C. Student learning performance and indoor environmental quality (IEQ) in air-conditioned university teaching rooms. Build. Environ. 2012, 49, 238-244. [CrossRef]

6. Wargocki, P.; Wyon, D. Providing better thermal and air quality conditions in school classrooms would be cost effective. Build. Environ. 2013, 59, 581-589. [CrossRef]

7. Alyami, S.H.; Rezgui, Y. Sustainable Building Assessment Tool Development Approach. Sustain. Cities Soc. 2012, 5, 52-62. [CrossRef]

8. Kamaruzzaman, S.N.; Lou, E.C.W.; Zainon, N.; Zaid, N.S.M.; Wong, P.F. Environmental assessment schemes for non-domestic building refurbishment in the Malaysian context. Ecol. Indic. 2016, 69, 548-558. [CrossRef]

9. Yang, H.; Abbaspour, K.C. Analysis of Wastewater Reuse Potential in Beijing. Desalination 212 (1e3), $238 \mathrm{e} 250$. Available online: http:/ / dx.doi.org/10.1016/j.desal.2006.10.012 (accessed on 10 November 2016).

10. Wei, W.; Ramalho, O.; Mandin, C. Indoor air quality requirements in green building certificátions. Build. Environ. 2015, 92, 10-19. [CrossRef]

11. Ghita, S.A.; Catalinab, T. Energy efficiency versus indoor environmental quality in different Romanian countryside schools. Energy Build. 2015, 92, 140-154. [CrossRef]

12. ASHRAE 55-2004. Thermal Environmental Conditions for Human Occupancy; American Society of Heating Refrigerating and Air Conditioning Engineers: Atlanta, GA, USA, 2004.

13. Fanger, P.O. Thermal comfort, Analysis and Applications in Environmental Engineering; McGraw-Hill: New York, NY, USA, 1972.

14. Barrett, P.; Davies, F.; Zhang, Y.; Barrett, L. The impact of classroom design on pupils' learning: Final results of a holistic, multi-level analysis. Build. Environ. 2015, 89, 118-133. [CrossRef]

15. Monteoliva, J.M.; Villalba, A.; Pattini, C. Correlated color temperature of daylight: Dynamic analysis in sunlit indoors. Inf. Constr. 2015, 67, e123. [CrossRef]

16. Correa, S.; Osorio, M.; Patiño, V. Economic valuation of noise: An analytical review of studies. Semest. Econ. 2011, 4, 53-76.

17. Freire, M.R. Natural Lighting in Classrooms: The Case of FAEC Schools in Salvador. Master's Thesis, Federal University of Rio Grande do, Porto Alegre, Brazil, 1996.

18. Nunes, R.T.S. Water Conservation in Commercial Buildings: Potential Rational Use and Water Reuse in Shopping Mall. Master's Thesis, Federal University of Rio de Janeiro, Rio de Janeiro, Brazil, 2006.

19. Jeong, Y.; Park, K.S. Sex differences in anthropometry for school furniture design. Ergonomics 1990, 33, 1511-1521. [CrossRef] [PubMed]

20. Portal Parque Escolar. Available online: https:/ /www.parque-escolar.pt/ (accessed on 28 November 2017).

21. JFminas. Available online: http:/ / www.jfminas.com.br/portal/historia/colegios (accessed on 10 June 2017).

22. Mateus, R. Sustainability Assessment of Construction-Proposals for the Development of Sustainable Buildings. Ph.D. Thesis, University of Minho, Guimarães, Portugal, 2009.

(C) 2018 by the authors. Licensee MDPI, Basel, Switzerland. This article is an open access article distributed under the terms and conditions of the Creative Commons Attribution (CC BY) license (http://creativecommons.org/licenses/by/4.0/). 